\title{
PHENOTYPIC AND GENOTYPIC DETECTION OF METHICILLIN- RESISTANT STAPHYLOCOCCUS AUREUS (MRSA) IN BROILER CHICKENS
}

\author{
AML A.M. BAKEET ${ }^{*}$ and SAMAH F. DARWISH ${ }^{* *}$ \\ ${ }^{*}$ Dept. of Poultry Diseases, Animal Health Research Instiute, Assiut, Egypt \\ ** Biotechnology Research Unit, Animal Reproduction Research Institute, El-Haram, Giza, Egypt \\ Email: d.aml-vet@yahoo.com
}

\section{ABSTRACT}

Received at: 30/9/2014

Methicillin-resistant Staphylococcus aureus (MRSA) has been increasingly reported

\section{(at: $30 / 9 / 2014$}

Accepted: 11/11/2014 as emerging problem in veterinary medicine, particularly in small animals and poultry. In Egypt, there is limited information on MRSA carriage in poultry. So the aim of this study was to investigate the prevalence of methicillin resistant staphylococci specifically MRSA in commercial broilers using both phenotypic and genotypic methods. A total of $87(72.5 \%)$ staphylococcal strains were isolated from 120 broiler chicken samples. Out of 87 isolates, $10(11.5 \%)$ were isolated from healthy chickens while the rest $77(88.5 \%)$ were recovered from diseased and dead chickens. Identification of these isolates was performed using combined phenotypic and genotypic methods. Phenotypic identification classified the Staphylococcal isolates into coagulase positive (CPS) and coagulase negative Staphylococci (CNS). Out of 87 staphylococcal strains 37(42 .5\%) were coagulase positive Staphylococci (CPS) while 50 (57.5\%) were coagulase negative Staphylococci (CNS). Studying the antibiotic Susceptibility profile of 37(CPS) staphylococcal strains against 12 antimicrobial agents revealed that the highest rate of resistant of staphylococcal species was observed to Ampicillin; Methicillin; Gentamicin and Trimethoprimsulfamethoxazole $(100 \%)$ while the highest rate of sensitivity was 59.5, 40.5, 29.7 and $21.6 \%$ for Vancomycin; Doxycycline; Streptomycin and Ciprofloxacin, respectively. Genotypic identification of twenty representative coagulase positive Staphylococcus isolates was performed using multiplex PCR assay. All the twenty isolates were found to be Staphylococci by successful amplification of the $228 \mathrm{bp}$ PCR product of the Staphylococcal specific 16S rRNA gene. Simultaneously, 12 out of them were confirmed to be $S$. aureus by successful amplification of $279 \mathrm{bp}$ PCR product of the $\mathrm{S}$. aureus specific thermonuclease gene while the rest of isolates were identified to be staphylococci other than S. aureus. All the confirmed S. aureus isolates in addition to 5 non $\mathrm{S}$. aureus strains were confirmed to be methicillin resistant through successful amplification of 147 bp specific products. In Conclusion, this study shows high incidence of methicillin resistant among staphylococci and specifically MRSA in broiler chickens including both healthy and diseased ,dead birds in Assiut Governorate, Egypt.

Key words: Phenotypic, genotypic, staphylococcus, broiler chickens.

\section{INTRODUCTION}

Pathogenic microorganisms resistant to commonly used antibiotics are a worldwide concern. In this regard, the bacterial pathogen Staphylococcus aureus is one of the most important bacteria, particularly its methicillin-resistant strains. After the introduction of methicillin in the 1960s, methicillin resistance was found in strains of $S$. aureus (Grundmann et al., 2006). Soon after, methicillinresistant Staphylococcus aureus (MRSA) in human populations has been reported worldwide becoming a significant cause for nosocomial and community onset infections. Currently, MRSA is causing a significant morbidity and mortality worldwide (Van Loo et al., 2007). Recently, MRSA has been increasingly reported as zoonotic and veterinary bacterial pathogen of public health importance and a problem in veterinary medicine, particularly in small animals (Walther et al., 2008). Strains isolated from pet animal cases were usually indistinguishable from those isolated from human. Pets become infected through contact with infected people, and those pets in turn pass MRSA back to humans indicating its 
zoonotic importance. MRSA are not only carried by pet animals but can also cause clinical disease in animals. MRSA have been found in number of animals including Dogs, Cats, Horses, Sheep, Pigs and Chickens. (Cuny et al., 2000; Lee, 2003; Kwon et al., 2006 and Becker, A. 2008). The first isolations of MRSA from animals were in milk from mastitic cows (Devriese et al., 1972). MRSA are classified by their ability to be resistant against oxacillin/methicillin, this feature being conferred by mecA, a gene which was acquired by horizontal gene transfer of the staphylococcal gene cassette (SCCmec). It is a genetic information that enables MRSA to be resistant against all penicillins, cephalosporins and carbapenems. In addition, MRSA are often resistant against a variety of other antiinfectives, i.e. aminoglycosides, macrolides, lincosamide, streptomycins, tetracyclin, chloramphenicol, but also against fluorquinolones and rifampicin (Walther et al., 2006). The extensive use of subtherapeutic doses of antimicrobial agents for growth production and routine disease prevention in food animals' often give rise to Multidrugresistant and MRSA strains in poultry $(\mathrm{Pu} \mathrm{S}$, et al., 2009). During recent years there have been several reports on the isolation of MRSA from poultry farms or slaughter houses, carcasses, or food of poultry origin. Studies have shown that transmission of S. aureus and MRSA can occur from human to animal and vice versa and direct exposure to MRSApositive animals may lead to transmission to humans (Persoons et al., 2009; Lim et al., 2010). Methicillin resistance was first observed in S. aureus isolates from chickens in Korea (Lee, 2003), Belgium (Persoons et al., 2009 and Pletinckx et al., 2011). MRSA was later detected in broiler chickens in Korea (Lim et al., 2010). A recent report from the Netherlands has documented the isolation of ST9 MRSA from chicken (Mulders et al., 2010 and GEENEN et al., 2013). In Malaysian chickens and chicken farmers, MRSA can be a colonizer and several disease patterns have been associated with them as comb necrosis, leg lameness because of arthritis or osteomyelitis, and septicaemia (Walther et al., 2000, MONECKE et al., 2013, Neela et al., 2013). MRSA was also able to colonize humans (Van Loo et al., 2007). Therefore, persons with occupational contact to livestock, such as farmers, veterinarians or abattoir workers, were especially at risk of being colonized by MRSA (Mulders et al., 2010 and Neela et al., 2013). Staphylococci including MRSA strains are cluster forming, facultative aerobic, Gram positive cocci with intrinsic ability to ferment carbohydrates, producing white to deep yellow pigmentation on solid culture media. They also ferment mannitol turning mannitol salt agar yellow. The organisms produce deoxyribonuclease (DNase) and catalase enzymes and coagulase proteins used for their identification (Bannerman, 2004). Methicillin is classified under narrow spectrum beta-lactamase resistance penicillins. It acts by interfering primarily with the synthesis of bacterial cell wall and produce effect by binding to penicillin binding proteins (PBPs). PBPs essentially involved in the maintenance of normal cell morphology and viability of bacteria. Drugs occupy the active site of transpeptidase enzyme and inactivate it. Inactivation of transpeptidation in cell wall synthesis leads to blockage of cell wall synthesis. Mutation on mecA gene which results in modification to PBP-2a, results in drugs not binding to target site and organism becomes resistant to $\beta$ lactams and other antibiotics with the same target site (Walther et al., 2008). Methicillin resistance requires the presence of mecA gene, so detection of mecA gene is the most reliable and fundamental method of identifying MRSA, this was done by PCR method which was accepted as a gold standard (Allaouchiche et al., 1999). In Egypt, there is limited information on MRSA carriage in poultry. So the aim of the current study was to investigate the prevalence of methicillin resistant staphylococcus aureus (MRSA) in commercial broilers using both phenotypic and genotypic methods. Additionally, in vitro susceptibility for additional antibiotics will be determined to provide an overview on the antimicrobial resistance profile of the isolated MRSA strains.

\section{MATERIALS and METHODS}

\section{Collection of broiler samples:}

Total number of 120 broiler samples were collected from apparently healthy broiler chickens $($ No. $=30)$ and diseased and dead chickens (No. =90). Samples were obtained from various private farms in Assiut Governorate, Egypt. Samples were nasal and cloacal swabs, hock joint and liver samples. All samples were taken under aseptic conditions.

\section{Isolation and identification}

The collected samples and swabs were inoculated into Tryptic soy broth (TSB) contaning $70 \mathrm{mg} / \mathrm{ml}$ $\mathrm{NaCl}$ and incubated at $37{ }^{\circ} \mathrm{C}$ for $24 \mathrm{~h}$. A loopful of the inoculated broth was subcultured on Baird Parker agar medium at $37{ }^{\circ} \mathrm{C}$ for $48 \mathrm{~h}$. The typical suspected colonies of being staphylococci were subcultured on blood agar plates with 5\% defibrinated sheep blood and tentatively identified according to morphological features, pigment production, type of haemolysis produced, gram staining, catalase test, coagulase test(in tubes) and characteristic growth on Mannitol salt agar which used as selective as well as differential medium for isolation and identification of Staphylococci according to the methods of Roberson et al. (1992), Sullia and Santharan (1998) and Quinn et al. (2004). 


\section{Antibiotics susceptibility testing}

The isolated staphylococci were tested for their antimicrobial susceptibility using the disk diffusion technique on Mueller-Hinton agar (Difco, Sparks, MD). The results were recorded after $24 \mathrm{~h}$ of incubation at $37^{\circ} \mathrm{C}$. The test was performed according to the method described in the guidelines of the Clinical and Laboratory Standards Institute (CLSI-2005). The zone of inhibition of each antibiotic disc was recorded. Methicillin; ME (5 $\mu \mathrm{g} /$ disk) was used to test the phenotypic expression of mecA genes. Ampicillin; AM (10 $\mu \mathrm{g} /$ disk), Enrofloxacin; ENR (5 $\mu \mathrm{g} /$ disk), Streptomycin; S (10 $\mu \mathrm{g} /$ disk$), \quad$ Vancomycin; $\mathrm{VA} \quad(10 \mu \mathrm{g} /$ disk$)$, Gentamicin; GN (10 $\mu \mathrm{g} /$ disc), Tetracycline; TE (30 $\mu \mathrm{g} /$ disk $)$, Trimethoprim-sulfamethoxazole; SXT(25 $\mu \mathrm{g} /$ disk), Neomycin; N (30 $\mu \mathrm{g} /$ disk), Ciprofloxacin;
CTP $(5 \mu \mathrm{g} /$ disk $)$; Doxycyclline; DO(30 $\mu \mathrm{g} /$ disk $)$ and Thiamphenicol; $\mathrm{TP}(30 \mu \mathrm{g} / \mathrm{disk})$ were also tested.

DNA extraction: A rapid boiling procedure was used to prepare template DNA from bacterial strains according to Reischl et al. (1994). Two to 5 loops of bacteria taken from the brain heart infusion agar plate were collected and suspended in $200 \mu \mathrm{l}$ of lysis buffer comprised of $1 \%$ Triton $\mathrm{X}-100,0.5 \%$ Tween 20, $10 \mathrm{mM}$ Tris- $\mathrm{HCl}(\mathrm{pH} 8.0)$, and $1 \mathrm{mM}$ EDTA. After boiling for $10 \mathrm{~min}$, the suspension was centrifuged for 2 min to sediment bacterial debris. The supernatant was aspirated, and from which $5 \mu 1$ was used directly for PCR amplification.

Primers: Primers used for PCR amplification were synthesized in Bio Basic Inc. (Canada). Details of primers sequences, their specific targets and products sizes are summarized in table (1).

Table 1: Primer sequaences, their specific targets and products sizes

\begin{tabular}{|c|c|c|c|}
\hline $\begin{array}{l}\text { Primer } \\
\text { name }\end{array}$ & $\begin{array}{l}\text { Primer sequence } 5^{\prime}-3^{\prime} \\
\text { (reference) }\end{array}$ & product size & Specificity \\
\hline $\begin{array}{l}\text { 16SrRNA f } \\
\text { 16SrRNAr }\end{array}$ & $\begin{array}{l}\text { 5' GTA GGT GGC AAG CGTTAT CC 3' } \\
\text { 5' CGC ACA TCA GCG TCA G 3' } \\
\text { (Monday and Bohach,1999) }\end{array}$ & $228 \mathrm{bp}$ & Staphylococcus genus specific primers \\
\hline $\begin{array}{l}\text { nuc } 1 \\
\text { nuc } 2\end{array}$ & $\begin{array}{l}\text { 5'-GCGATTGATGGT GATACGGTT-3' } \\
\text { 5'-AGCCAAGCCTTGACGAACTAAAGC-3 ' } \\
\text { (Brakstad et al., 1992) }\end{array}$ & 279 bp & S. aureus specific primers \\
\hline $\begin{array}{l}\operatorname{mecA} \mathbf{f} \\
\operatorname{mecA} \mathbf{r}\end{array}$ & $\begin{array}{l}\text { 5' GTG AAG ATA TAC CAA GTG ATT 3' } \\
\text { 5' ATG CGC TAT AGA TTG AAA GGA T 3' } \\
\text { (Zhang et al., 2005) }\end{array}$ & $147 \mathrm{bp}$ & Methicilin resistant Staphylococci \\
\hline
\end{tabular}

\section{Multiplex Polymerase Chain Reaction (PCR):}

A multiplex PCR assay targeting 16S rRNA (Staphylococcus genus specific), nuc (S. aureus species specific), and mecA (a determinant of methicillin resistance) was used. It was established using a total volume of $25 \mu \mathrm{l}$ reaction mixtures contained $5 \mu 1$ of DNA as template, 20 pmol of each primer and $1 \mathrm{X}$ of PCR master mix (Dream Taq Green PCR Master Mix, Fermentas Life Science). The amplification cycles were carried out in a PT100 Thermocycler (MJ Research, USA). Reaction conditions were optimized to be $94^{\circ} \mathrm{C}$ for $4 \mathrm{~min}$. as initial denaturation, followed by 35 cycles of $94^{\circ} \mathrm{C}$ for 60 seconds, $55^{\circ} \mathrm{C}$ for 60 seconds and $72{ }^{\circ} \mathrm{C}$ for 60 seconds. A final extension step at $72^{\circ} \mathrm{C}$ for $10 \mathrm{~min}$. was followed. DNA isolated from mec A positive laboratory S. aureus strain was used as positive controls while water was used as negative controls (no template). Both positive and negative controls were included to exclude both amplification failures due to presence of inhibitors and cross contamination. Amplification products were electrophorezed in $1.5 \%$ agarose gel containing $0.5 \mathrm{X}$ TBE at 70 volts for $60 \mathrm{~min}$. and visualized under ultraviolet light. To assure that the amplification products were of the expected size, a $100 \mathrm{bp}$ DNA ladder was run simultaneously as a DNA marker. Amplification of both 228 and 279 bp bands indicated the isolate to be $\mathrm{S}$. aureus while amplification of $228 \mathrm{bp}$ only indicated the strain to be Staphylococci other than S. aureus. Amplification of the $147 \mathrm{bp}$ fragment confirmed the isolate to be methicilin resistant.

\section{RESULTS}

Based on the identification methods used in our study, a total of $87(72.5 \%)$ staphylococcal strains were isolated from 120 broiler chicken samples. Out of 87 isolates, $10(11.5 \%)$ were isolated from healthy chickens while the rest $77(88.5 \%)$ were recovered 
from diseased and dead chickens. Identification of these isolates was performed using combined phenotypic and genotypic methods. Phenotypic identification classified the Staphylococcal isolates into coagulase positive (CPS) and coagulase negative Staphylococci (CNS). Out of 87 staphylococcal strains 37(42.5\%) were coagulase positive Staphylococci (CPS) and 50 (57.5\%) were coagulase negative Staphylococci (CNS). Table (2) shows number and percentages of coagulase positive and coagulase negative staphylococci isolated from healthy and diseased and dead chickens.

Bacteriological identification revealed that colonies of Staphylococci on Baird Parker agar medium were black, shiny and convex surrounded by clear zone. Also there was a characteristic golden yellow growth on Mannitol salt agar. Also, the staphylococcal isolates showed beta-heamolysis on blood agar medium. Microscopic characters were gram positive cocci in clusters. All isolates were catalase positive.

Results of antibiotic Susceptibility profile of 37(CPS) staphylococcal strains against 12 antimicrobial agents are summarized in table (4). Studying the antibiotic Susceptibility profile of 37(CPS) staphylococcal strains against 12 antimicrobial agents revealed that the highest rate of resistant of staphylococcal species was observed to Ampicillin; Methicillin; Gentamicin and Trimethoprimsulfamethoxazole $(100 \%)$ while the highest rate of sensitivity was 59.5, 40.5, 29.7 and $21.6 \%$ for Vancomycin; Doxycycline; Streptomycin and Ciprofloxacin, respectively.

Genotypic identification of twenty representative coagulase positive Staphylococcus isolates was performed by multiplex PCR assay (Figure 1). Multiplex PCR confirmed the twenty isolates to be Staphylococci by successful amplification of the 228 bp PCR product of the Staphylococcal specific $16 \mathrm{~S}$ rRNA gene. Simultaneously, only 12 out of the 20 isolates were confirmed to be S. aureus by successful amplification of $279 \mathrm{bp} \mathrm{PCR} \mathrm{product} \mathrm{of} \mathrm{the} \mathrm{S.} \mathrm{aureus}$ specific thermonuclease gene while the rest of isolates were identified to be staphylococci other than S. aureus. All the $12 \mathrm{~S}$. aureus isolates in addition to 5 non aureus strains were confirmed to be methicillin resistant through successful amplification of $147 \mathrm{bp}$ specific products (table 3 ).

Table 2: Incidence of staphylococci species in examined broiler chicken

\begin{tabular}{cccccccc}
\hline $\begin{array}{c}\text { Source of } \\
\text { samples }\end{array}$ & $\begin{array}{c}\text { Number of } \\
\text { samples }\end{array}$ & $\begin{array}{c}\text { No. of staphylococci } \\
\text { species isolates }\end{array}$ & $\%$ & $\begin{array}{c}\text { No. of (CPS) } \\
\text { staphylococci }\end{array}$ & $\%$ & $\begin{array}{c}\text { No. of (CNS) } \\
\text { staphylococci }\end{array}$ & $\%$ \\
\hline $\begin{array}{c}\text { healthy } \\
\text { chickens }\end{array}$ & 30 & 10 & 11.5 & 8 & 80 & 2 & 20 \\
$\begin{array}{c}\text { (nasal, cloacal } \\
\text { swabs) }\end{array}$ & 77 & 88.5 & 29 & 37.7 & 48 & 62.3 \\
\hline $\begin{array}{c}\text { Diseased, dead } \\
\text { chickens (hock } \\
\text { joint, liver) }\end{array}$ & 90 & 77 & & & & & \\
\hline
\end{tabular}


Assiut Vet. Med. J. Vol. 60 No. 143 October 2014

\begin{tabular}{llllllll}
\hline Total & 120 & 87 & 72.5 & 37 & 42.5 & 50 & 57.5 \\
\hline
\end{tabular}

Table 3: Genotypic identification of (20) coagulase positive staphylococcal species

\begin{tabular}{cccc}
\hline $\begin{array}{c}\text { No. of coagulase positive } \\
\text { staphylococci }\end{array}$ & 16srRNA PCR result & Nuc PCR result & mecA PCR result \\
\hline & & 12 (S.aureous) & 12 \\
\cline { 2 - 4 } 20 & 20 & 8 (non S.aureous) & 5 (mecA positive) \\
& & 3 (mec A negative) \\
\hline
\end{tabular}


Table 4: Susceptibility testing of coagulase positive S. aureus isolated from chickens.

\begin{tabular}{|c|c|c|c|c|c|}
\hline \multirow[b]{2}{*}{ Antimicrobial agent } & \multirow[b]{2}{*}{ Disk potency $(\mu \mathrm{g})$} & \multicolumn{2}{|c|}{ Sensitive isolates } & \multicolumn{2}{|c|}{ Resistant isolates } \\
\hline & & Number & $\%$ & Number & $\%$ \\
\hline Doxycycline (DO) & $30 \mu \mathrm{g}$ & 15 & 40.5 & 22 & 59.5 \\
\hline Ampicillin (AM) & $10 \mu \mathrm{g}$ & $\mathbf{0}$ & $\mathbf{0}$ & 37 & 100 \\
\hline Enrofloxacin (ENR) & $5 \mu \mathrm{g}$ & 4 & 10.8 & 33 & 89.2 \\
\hline Neomycin $(\mathbf{N})$ & $30 \mu \mathrm{g}$ & 3 & 8.1 & 34 & 91.9 \\
\hline Trimethoprim-sulphamethaxole (SXT) & $25 \mu \mathrm{g}$ & $\mathbf{0}$ & $\mathbf{0}$ & 37 & 100 \\
\hline Tetracyclin (TE) & $30 \mu \mathrm{g}$ & 4 & 10.8 & 33 & 89.2 \\
\hline Streptomycin (S) & $10 \mu \mathrm{g}$ & 11 & 29.7 & 26 & 70.3 \\
\hline Vancomycin (VA) & $30 \mu \mathrm{g}$ & 22 & 59.5 & 15 & 40.5 \\
\hline Ciprofloxacin (CIP) & $5 \mu g$ & 8 & 21.6 & 29 & 78.4 \\
\hline Methicillin (ME) & $5 \mu \mathrm{g}$ & $\overline{\mathbf{0}}$ & $\mathbf{0}$ & 37 & 100 \\
\hline Thiamphenicol (TP) & $30 \mu \mathrm{g}$ & 7 & 18.9 & 30 & 81.1 \\
\hline Gentamycin (GN) & $10 \mu \mathrm{g}$ & $\mathbf{0}$ & $\mathbf{0}$ & 37 & 100 \\
\hline
\end{tabular}

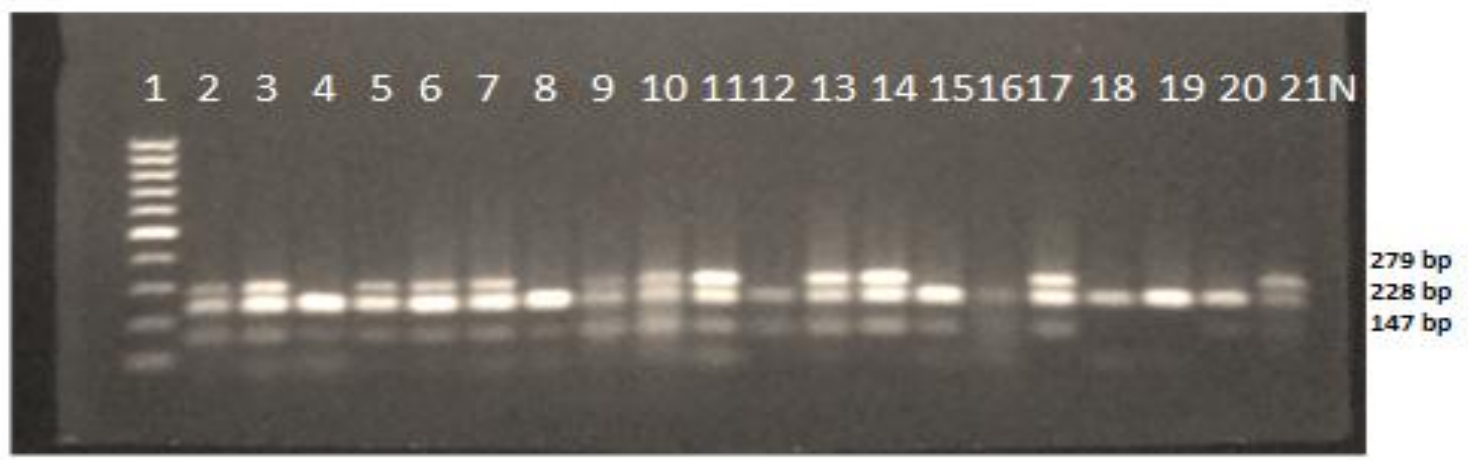

Figure 1: Multiplex PCR assay targeting the 16SrRNA (228bp), nuc (279bp) and mecA (147bp) genes simultaneously in Staphylococcal strains.

Lane 1: 100 bp DNA ladder, Lane 2: methicillin resistant $S$. aureus (positive control); Lane 3, 5-7, 9-11, 13, 14, 17, 21: methicillin resistant S. aureus isolates; lanes 4,8,12,15,20: methicillin resistant non S. aureus isolates; Lanes 16,18, 19: methicillin sensitive non $\mathrm{S}$. aureus isolates; lane $\mathrm{N}$ : negative control.

\section{DISCUSSION}

In recent years, Methicillin-resistant Staphylococcus aureus (MRSA) has been increasingly reported as emerging problem in veterinary medicine, particularly in small animals and poultry (Cunny et al., 2000; Kwon et al., 2006). Several reports shows the presence of MRSA in a variety of poultry farms, slaughter houses, carcases, or food of poultry origin (Nemati et al., 2008; Persoons et al., 2009; Lim et al., 2010). This is leading to an upsurge of reports and interest in MRSA colonization and infection in poultry. Screening the prevalence of MRSA will be of much use in early prevention and 
control of MRSA colonization and spreading in poultry flocks specially immunocompromised birds and community acquired infections. Hence, this study was carried out to address the prevalence of MRSA among diseased and healthy broiler chickens in Assiut province. Moreover, the antibiotics susceptibility pattern of these isolates will be studied. In the current study, 87 Staphylococcal isolates were isolated from 120 broiler samples in a percentage of $72.5 \%$. Studying the phenotypic characters of these isolates revealed that these isolates were classified into CPS (No. $=37,42.5 \%)$ and CNS (No. $=50$, $57.5 \%$ ). The incidences of CNS among isolates recovered from broiler samples were higher than CPS. These relatively high incidences came in agreement to those reported by (Junichi K. et al., 1996) who isolated 72 CNS isolates from the nares and skin of 280 chicken aged 1-8 weeks old in percentage of $25.7 \%$. The extensive use of antimicrobial agents in food animals' and in poultry husbandry often give rise to multidrug resistant and MRSA strains in poultry (Pu S. et al., 2009). For specific treatment of staphylococcal infections in poultry, veterinarians generally use penicillin, erythromycin, and tetracycline (Tanner, 2000 and White et al., 2003). Antibiotic susceptibility profile of the isolates tested in this study demonstrated high resistant (100\%) of MRSA strains to Ampicillin, Methicillin, Gentamycin and Trimethoprimsulfamethoxazole. This finding was reported elsewhere, Lee (2003); Quddoumi et al. (2006); Nemati et al. (2008) and OKE and Adewale (2013). While we disagree with Walther et al. (2006); Nemati et al. (2008); Persoons et al. (2009) and Nemeghaire et al. (2013) who reported that MRSA isolates were have multidrug resistant to erythromycin, tetracycline, and streptomycin. In our study resistance to Neomycin, Enrofloxacin, Tetracycline, Thiamphenicol and Ciprofloxacin were $91.8,89,89,81$ and $78 \%$, respectively. These results partially come in accordance with Mulders et al. (2010) who recorded that, in vitro antibiotic resistance was $89 \%$ for tetracycline, $26 \%$ for neomycin and $42 \%$ for Ciprofloxacin and Neela et al. (2013) who recorded that all isolates were Ciprofloxacin resistant. On the other hand, our results showed that $59 \%$ of the isolates were sensitive to vancomycin, this high percentage of sensitivity was recorded by Quddoumi et al. (2006), while Lee (2006); Nemeghaire et al. (2013) and Neela et al. (2013), mentioned that all MRSA isolates were susceptible to vanomycin.

A multiplex PCR, utilizing three pair of primers simultaneously, was used both for identification of the isolated Staphylococci and for detection of Methicillin-mediated resistance gene. The performed multiplex PCR assay confirmed all the tested 20 isolates to be Staphylococci through successful amplification of the 228 bp fragment of
Staphylococcal specific 16S rRNA gene (Fig 1). Using the same multiplex PCR, some isolates were confirmed to be $\mathrm{S}$. aureus through successful amplification of 279 bp fragment of S. aureus specific thermonuclease gene. Out of 20 representative Staphylococcus isolates recovered from broiler chickens, 12 isolates were S. aureus while the rest 8 isolates were not $\mathrm{S}$. aureus. Considering mecA, all the $12 \mathrm{~S}$. aureus isolates were methicillin resistant carrying mecA gene (MRSA), while 5 out of 8 non S. aureus isolates were also mecA positive while the rest 3 isolates were not carrying mecA gene. This results was in agreement with Quddoumi et al. (2006) who found 15 out of 30 S. aureus isolated from sheep and chicken to be MRSA strains (mecA positive). Also, nearly similar results were reported by Lee. (2003). They isolated $421 \mathrm{~S}$. aureus strains from cattle, pig and chickens samples. Among their samples, 28 isolates were confirmed to be MRSA strains by PCR (mecA positive). Additionally, Abdulkadir et al. (2007) recovered 9 MRSA strains from 50 chickens in Malaysia while Nemati et al. (2008) reported that 81 S. aureus isolates identified genotypicaly from noses and cloacae of healthy chickens were carrying mecA gene and so confirmed to be MRSA. Also, Persoons et al. (2009) isolated 8 MRSA isolates from nares and cloaca of broiler chickens. Mulders et al. (2010) found high prevalence of MRSA in broiler isolates 28 isolates were mecA positive. The latest researches proved that MRSA is a distributed worldwide in poultry farms including the people in contact with poultry operations, OKE and Adewale (2013). They estimated the prevalence of MRSA to be $95 \%$ and $83 \%$ in chickens with diarrhea and poultry attendants, respectively. On the contrary, Geenen et al. (2013) mentioned the prevalence of MRSA strains to be $8 \%$ in Dutch broiler farms. Furthermore, $66.7 \%$ of the people living and/or working on these positive farms were MRSA positive. Also Wendlandt S., et al. (2013) confimed these previous results by isolation of 31 MRSA strains carrying mecA gene from broiler, broiler houses and 6 from humans. Wendlandt S., (2014) isolated 28 strains from broiler and 18 from humans in contact. Phenotypic methods were found to be time consuming and labor intensive. Moreover, performing disk diffusion tests was also reported to lead to false positive and false negative results. On the other hand, several advantages were reported for genotypic methods in resistance detection compared to conventional susceptibility methods. Genotypic tests provide resistance profiles rapidly, diminish the biohazard risk associated with the propagation of a microorganism by culture and it can be used as a gold standard for evaluating new, improved susceptibility methods for testing clinical isolates with difficult-to-detect resistance profiles where CLSI guidelines now accepted that checking for presence of mecA by PCR is the most reliable 
method for detection of MR (Rasheed and Tenover, 2003). To the best of our knowledge in this study, we detect for the first time MRSA, stains from healthy and diseased broiler chickens in Assiut, Egypt specially by genotypic method.

In Conclusion, this study shows high incidence of methicillin resistant among staphylococci and specifically MRSA in broiler chickens including both healthy and diseased birds in Assiut, Egypt. This finding was confirmed by both phenotypic and genotypic methods. Therefore, follow-up studies are needed to assess the degree of exposure of broiler chicken flocks to MRSA to understand the risk factors involved and to develop guidelines for intervention.

\section{REFRENCES}

Abdulkadir, M.M.; Zunita, Z.; Goh, Y.M.; Saleha, A.A. and Son, R. (2007): Occurrence of methicillin -resistant Staphylococcus aureus (MRSA) in chickens Proceeding of 19 th Veterinary Association Malaysia congress Aug. 3-5 Malaysia, pp 182-185.

Allaouchiche, B.; Jaumanin, H.; Zambardi, G.; Chassard, D. and Freney, J. (1999): Clinical impact of rapid oxacillin susceptibility testing using a PCR assay in Staphylococcus aureus bacteremia. J. Infect. 39, 198-204.

Bannerman, T.L. (2004): Staphylococcus, Micrococcus and other catalase- positive cocci that grow aerobically In Manual of Clinical Microbiology P.R. Murray, E.J. Baron, J.H. Jorgensen, M.A. pfaller and R.H. Yolken eds. 8th edition, ASM Press Washington DC.

Becker, A. (2008): Methicillin Resistant Staphylococcus aureus (MRSA) isolated from small and exotic animals at a university hospital during routine microbiological examinations Vet. Microbiol. 127, 171-178.

Brakstad, O.G.K. Asbakk and Maeland, J.A. (1992): Detection of staphylococcus aureus by polymerase chain reaction amplification of the nuc gene. J. Clin. Microbiol., 30: 1654-1660.

CLSI (2005): Performance Standards for antimicrobial susceptibility testing. CLSI, approved standard M100-S15. Clinical and Laboratory Standards Institute, Wayne, PA; 2000.

Cuny, C., A. Friedrich, s. kozytska, f. layer, u. nübel, Ohlsen, K.; Strommenger, B.; Walther, B.; Wieler, L.; Witte, W. (2000): Emergence of methicillin resistant Staphylococcus aureus(MRSA) in different animal species. Int. J. Med. Microbiol 300 109-17.

Devriese, L.A.; Vandamme, L.R. and Fameree, L. (1972): Methicillin (cloxacillin)-resistant Staphylococcus aureus strains isolated from bovine mastitis cases. Zentralblatt fur Veterinarmedizin B 19, 598-605.

Geenen, P.L.; Graat, E.A.; Haenen, A.; Hengeveld, P.D.; Van hoek, A.H.; Huijsdens, X.W.; Kappert, C.C.; Lammers, G.A.; Van Duijkeren, E. and Van De Giessen, A.W. (2013): Prevalence of livestock-associated MRSA on Dutch broiler farms and in people living and/or working on these farms.Epidemiol. Infect. 141, 1099-108.

Grundmann, H.; Aires-de-Sousa, M.; Boyce, J. and Tiemersma, E. (2006): Emergence and resurgence of Methicillin -resistant Staphylococcus aureus as a public health threat. Lancet, 368: 874-885.

Junichi Kawano; Shimizu, A.; Saitoh, Y.; Yagi, M.; Saito, T. and Okamoto, R. (1996): Isolation of methicillin-resistant coagulase-negative staphylococci from chickens. J. Clin. Microbiol 34 (9): 2072.

Kwon, N.H.; Park, K.T.; Jung, W.K.; Youn, H.Y.; Lee, Y.; Kim, S.H.; Bae, W.; Lim, J.Y.; Kim, J.Y.; Kim, J.M.; Hong, S.K. and Park, Y.H. (2006): Characteristics of methicillin resistant Staphylococcus aureus isolated from chicken meat and hospitalized dogs in Korea and their epidemiological relatedness. Vet. Microbiol. 117, 304-312.

Lee, J.H. (2003): Methicillin (oxacillin) resistant Staphylococcus aureus strains isolated from major food animals and their potential transmission to humans. Appl. Environ. Microbiol. 69, 6489-6494.

Lee, JH. (2006): Occurrence of methicillin-resistant Staphylococcus aureus strains from cattle and chicken, and analyses of their mecA, mecR1 and mecI genes. Vet. Microbiol.; 114: 155-9.

Lim, SK.; Nam, HM.; Park, HJ.; Lee, HS.; Choi, MJ.; Jung, SC.; Lee, JY.; Kim, YC.; Song, SW. and Wee, SH. (2010): Prevalence and characterization of methicillin-resistant Staphylococcus aureus in raw meat in Korea. J. Microbiol. Biotechnol, 20: 775-778.

Monday, S.R. and Bohach, G.A. (1999): Use of multiplex PCR to detect classical and newly described pyrogenic toxin genes in staphylococcal isolates. J. Clin. Microbiol., 37: 3411-3414.

Monecke, S.; Ruppelt, A.; Wendlandt, S.; Schwarz, S.; Slickers, P.; Ehricht, R. and Jäckel, S.C. (2013): Genotyping of Staphylococcus aureus isolates from diseased poultry. Vet. Microbiol. $162,806-12$.

Mulders, MN.; Haenen, APJ.; Geenen, PL.; Vesseur, PC.; Poldervaart, ES.; Bosch, T.; Huijsdens, XW.; Hengeveld, PD.; Dam-Deisz, WDC. and Graat, EAM. (2010): Prevalence of livestockassociated MRSA in broiler flocks and risk factors for slaughterhouse personnel in The Netherlands. Epidemiol. Infect., 138: 743-755. 
Neela, V.; Ghaznavi-Rad, E.; GhasemzadehMoghaddam, H.; Nor Shamsudin, M.; Belkum, A. and Karunanidhi, A. (2013): Frequency of methicillin resistant Staphylococcus aureus in the noses of Malaysian chicken farmers 2013, and their chicken. Iranian Journal of Veterinary Research, Shiraz University, 14: 226-231

Nemati, M.; Hermans, K.; Lippinska, U.; Denis, O.; Deplano, A.; Struelens, M.; Devriese, L.A.; Pasmans, F. and Haesebrouck, F. (2008): Antimicrobial resistance of old and recent Staphylococcus aureus isolates from poultry: first detection of livestock-associated methicillin-resistant strain ST398. Antimicrob. Agents Chemother, 52 (10): 3817-3819

Nemeghaire, S.; Sophie, R.; Angeles., M.; Haesebrouckand, F. and Butaye, P. (2013): Characterization of methicillin -resistant Staphylococcus aureus from health carrier chickens. Avian Pathology -vol. 4: 342-346.

Oke, A.J. and Adewale, A.O. (2013): Incidence of Methicillin-Resistant Staphylococcus aureus (MRSA) In a Small Poultry in South West, Nigeria. IOSR Journal of Agriculture and Veterinary Science (IOSR-JAVS), 5 (3): 53-55.

Persoons, D.; Van Hoorebeke, S.; Hermans, K.; Butaye, P.; De Kruif, A.; Haesebrouck, F. and Dewulf, J. (2009): Methicillin-resistant Staphylococcus aureus in poultry. Emerg. Infect. Dis., 15(3): 452-3.

Pletinckx, L.J.; Verhegghe, M.; Dewulf, J.; Crombé, F.; DE Bleecker, Y.; Rasschaert, G.; Goddeeris, B.M. and DE Man, I. (2011): Screening of poultry -pig farms for methicillin-resistant Staphylococcus aureus :sampling methodology and within herd prevalence in broiler flocks and pigs. Infect. Genet. Evol. 11, 2133-7.

Pu, S.; Han, F. and Ge, B. (2009): Isolation and characterization of Methicillin- Resistant Staphylococcus aureus strains from Louisiana retails meats. Appl. Environ Microbiol.75: 265-267.

Quddoumi, S.S.; Salwa, M.B. and Adel, M.M. (2006): Isolation and characterization of MethicillinResistant Staphylococcus aureus from livestock and poultry meat. Ann.Microbiol.56: 155-161.

Quinin, P.J.; Carter, M.E.; Markey, B. and Carter, G.R. (2004): Clinical veterinary microbiology printed in Spain by Grafos, S.A. Arte Sobre Pape J.

Rasheed, J.K. and Tenover, F.C. (2003): Detection and characterization of antimicrobial resistance genes in bacteria. In:Murray, P.R., E.J. Baron, J.H. Jorgensen, M.A. Pfaller and R.H. Yolken, eds. Man. Clin. Microbiol., $8^{\text {th }}$ edition, Washington, DC: ASM, pp: 1196-1212.

Reischl, U.; Pulz., M.; Ehret, W. and Wolf., H. (1994): PCR-based detection of mycobacteria in sputum samples using a simple and reliable DNA extraction protocol. Bio. Techniques., 17: 844-845.

Roberson, J.R.; Fox, L.K. and Hancock., D.D. ( 1992): Evaluation methods for differentiation of coagulase positive staphylococci. J. Clin. Microbiol., 30: 3217-3219.

Sullia, S.B. and Shantharam, S. (1998): General Microbiology. 1st. Ed. Oxford \& IBH Publishing Co. New Delhi, 549562.

Tanner, A.C. (2000): Antimicrobial drug use in poultry, p. 637-655. In J. F. Prescott, J. D. Baggot, and R.D. Walker (ed.), Antimicrobial therapy in veterinary medicine. Iowa State University Press, Ames, IA.

Van Loo, I.; Huijsdens, X.; Tiemersma, E.; De neeling, A.; Van de sande- Bruinsma, N.; Beaujean, D.; Voss, A. and Kluytmans, J. (2007): Emergence of methicillin-resistant Staphylococcus aureus of animalorigin in humans, Emerg. Infect. Dis.13, 1834-9.

Walther, B.; Wieler, L.H.; Friedrich, A.W.; Hanssen, A.M.; Kohn, B.; Brunnberg, L. and LubkeMCNAMEE, P.T. and SMYTH, J.A. (2000): Bacterial chondronecrosis with osteomyelitis ('femoral head necrosis') of broiler chickens: a review. Avian. Pathol.29, 477-95.

Walther, $B^{l}$.; Friedrich, AW.; Brunnberg, L.; Wieler, LH. and Lübke-Becker, A. (2006): [Methicillin-resistant Staphylococcus aureus (MRSA) in veterinary medicine: a "new emerging pathogen"?].Berl Munch Tierarztl Wochenschr. 119 (5-6): 222-32.

Walther, B.; Wieler, L.H.; Friedrich, A.W.; Hanssen, A.M.; Kohn, B.; Brunnberg, L. and LubkeBecker, A. (2008): Methicillin-resistant Staphylococcus aureus (MRSA) isolated from small and exotic animals at a university hospital during routine microbiological examinations. Vet. Microbiol. 127, 171-178.

Wendlandt, S. (2014): Comparative molecular analysis of Staphylococcus aureus from intensive livestock farming with emphasis on LA-MRSA of poultry origin. (Ph.D.) THESIS. University of Veterinary Medicine Hannover Friedrich-Loeffler-Institut, Institute of Farm Animal Genetics, Neustadt- Mariensee, Germany.

Wendlandt, S.; Kadlec, K.; Fessler, AT.; Mevius, D.; Van Essen-Zandbergen, A.; Hengeveld, PD.; Bosch, T.; Schouls, L.; Schwarz, S. and Van Duijkeren, E. (2013): Transmission of methicillin-resistant Staphylococcus aureus isolates on broiler farms. Vet. Microbiol .27; 167(3-4): 632-7. 
White, D.G.; Ayers, S.; Maurer, J.J.; Thayer, S.G. and Hofacre, C. (2003): Antimicrobial susceptibilities of Staphylococcus aureus isolated from commercial broilers in Northeastern Georgia. Avian Dis. 47: 203210. [PubMed].
Zhang, K.; McClure, J.A.; Elsayed, S.T.; Louie, T. and Conly, J.M. (2005): Novel multiplex PCR assay for characterization and concomitant subtyping of staphylococcal cassette chromosome mec types I to $\mathrm{V}$ in methicillin resistant Staphylococcus aureus. J. Clin. Microbiol., 43: 5026-5033.

\title{
الكثف الظاهرى والجينى عن ميكروب المكور العنقودى الذهبى المقاوم للميثا سيلين فى بلارى التسمين
}

\author{
أمل أحمد بخيت ، سماح لرويش
}

Email: d.aml-vet@yahoo.com

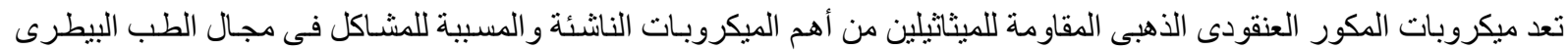

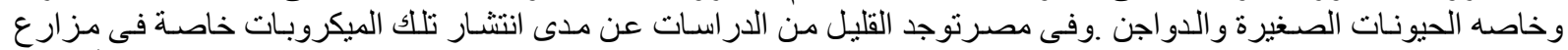

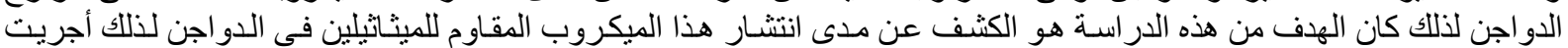

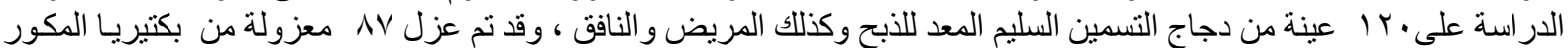

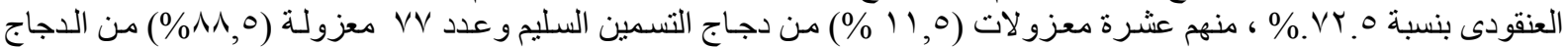

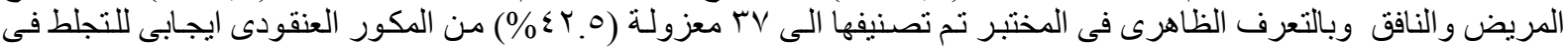

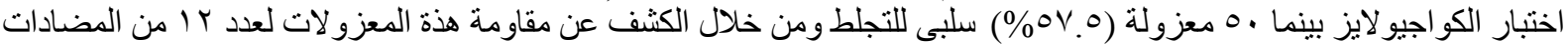

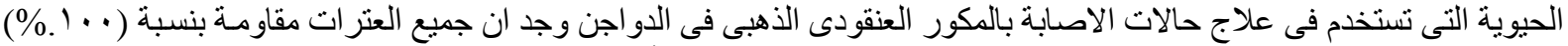

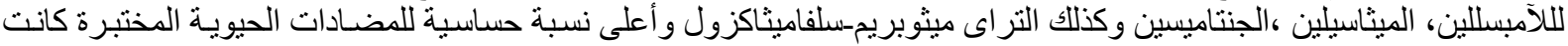

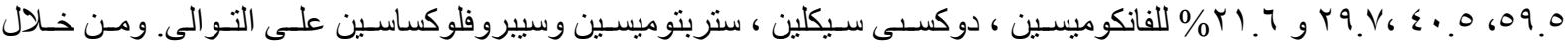

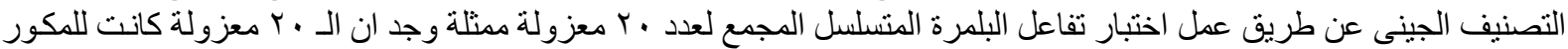

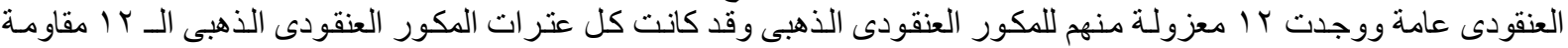

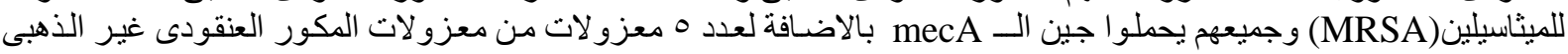

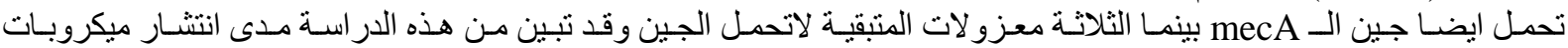

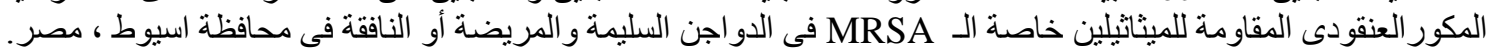

